\title{
$74^{\text {sTE }}$ VERGADERING VAN HET BESTUUR,

\author{
GEHOUDEN TE 'S GRAVENHAGE
}

DEN $17^{\text {DEN }}$ APRIL 1863.

Tegenwoordig de heeren Cornets de Groot, Potter, Keyzer, Brunsveld van Hulten, Engelhard, Willer en de $2^{\text {de }}$ Secretaris. De notulen der vorige vergadering worden gelezen en goedgekeurd.

De Voorzitter berigt, dat de heer P. Hofstede de Groot zijn ontslag heeft genomen als lid des Instituuts.

Door de vergadering worden tot leden des Instituuts benoemd de heeren:

Jhr. Mr. J. K. J. de Jonge, te 's Hage,

A. J. A. Gerlach, id.

P. J. B. C. Robidé van der Aa, id.

C. J. M. Nagtglas, id.

Mr. A. M. de Rouville, te Brielle.

J. Ellis, te Amsterdam.

Mr.... Barnet Lyon, te Brussel.

J. Zaal, te Amsterdam.

R. F. van Lansberge,

F. Carstairs,

Dr. F. A. C. Dumontier,

Mr. E. A. van Emden,

T. J. Eyken Sluyters,

Mr. J. M. Ganderheyden,

H. van Genderen,

J. H. A. W. baron van Heerdt tot Eversberg,

J. de Jong,

Dr. J. J. Juda,

Dr. C. Landré,

Mr. G. J. A. Bosch Reitz,

H. G. Roux,

E. J. Slengarde,

M. S. van Praag,

J. van Praag,

A. M. Coster,

Allen te

Paramaribo. 

J. D. Crol,
Mr. J. H. Beaujon,
$\left.\begin{array}{l}\text { Mr. P. Cockburn Prince, } \\ \text { Dr. N. Rojer, } \\ \text { Dr. T. de Veer. }\end{array}\right\}$ Allen te Curaçao.
C. L. Daniels
en A. Magnin. $\}$ Aan de Kust van Guinea.

De Voorzitter berigt, dat zijn ingekomen:

10. Eene missive van den Minister van Koloniën ten geleide van het Verslag van het beheer en den staat der kolonien en bezittingen van het Rijk in andere werelddeelen over 1860 - wordt besloten dit verslag te plaatsen in de boekerij des Instituuts.

$2^{\circ}$. Verzoeken van de $1^{\text {ste }}$ en $2^{\text {de }}$ afdeeling om exemplaren der “Bepalingen voor de afdeelingen;” wordt besloten die “Bepalingen" te laten drukken, aan die verzoeken te voldoen en ook de andere afdeelingen daarvan te voorzien.

$3^{3}$. Nota van de $2^{\text {de }}$ afdeeling houdende rapport omtrent het opstel van den heer van Doren over de Tenimber-eilanden. $\mathrm{Na}$ voorlezing van dat rapport en van de inlichtingen, omtrent dat opstel van den heer Weddik te Utrecht ingewonnen, wordt besloten, om het artikel in de "Bijdragen" op te nemen.

$4^{\circ}$. Een berigt van den secretaris der $3^{\text {de }}$ afdeeling, dat het voorzitterschap dier afdeeling, gedurende de afwezigheid van den heer Gallois, door den heer Keyzer zal worden waargenomen. Aangenomen voor kennisgeving.

$5^{\circ}$. Een schrijven van de $4^{\text {de }}$ afdeeling, houdende $a$ berigt, dat zij zich geconstitueerd heeft en mededeeling van haar bestuur; $b$ voorstel tot benoeming van leden in de West-Indiën; $c$ voorstel tot het uitgeven van wege het Instituut van den "Almanak voor de Nederlandsche West-Indische bezittingen en de Kust van Guinea," waarvan de uitgave sedert 1862 is gestaakt; $d$ toezending van een tiental vraagpunten ter opname in de "Bijdragen" des Instituuts.

De mededeeling sub $a$ wordt voor kennisgeving aangenomen en daar aan het voorstel sub $b$, blijkens bovenvermelde benoeming, reeds gevolg is gegeven, wordt dat sub $c$ in behandeling genomen. Uit de discussiën over dit punt blijkt, dat men de wederuitgave van den Almanak, ofschoon niet ten laste van het Instituut, gaarne zal ondersteunen. 
De Voorzitter wordt dan ook uitgenoodigd deswegens in overleg te treden met den Voorzitter der $4^{\text {de }}$ afdeeling en nadere voorstellen aan het Bestuur te doen. - De vragen, vermeld sub $d$, worden aan den eersten secretaris ter hand gesteld.

Daarna wordt besloten de heeren Roorda en Keyzer te verzoeken aan het Bestuur voorstellen te doen omtrent de geschikste wijze om, tot bevordering van het doel des Instituuts, betrekkingen aan te knoopen met de Koninklijke Akademie ter opleiding van ambtenaren voor Nederl. Indië, en zulks naar aanleiding van art. 3 van het reglement, dat in dit opzigt tot dus ver zonder gevolg is gebleven.

Op voorstel van den Voorzitter wordt verder besloten den 9 den Mei aanstaande eene algemeene vergadering te houden, en daarin een verslag uit te brengen van den staat en de werkzaamheden des Instituuts gedurende het afgeloopen Instituutsjaar, waarvan het ontwerp wordt voorgelezen en goedgekeurd. Ook worden de drietallen aangewezen ter vervulling op die algemeene vergadering van de vacatures, welke door de gewone aftreding van drie zijner leden in het Bestuur ontstaan zullen.

De heer Keyzer deelt de nadere voorwaarden mede, waarop de heer Muller de uitgave van het werk des heeren van der Chijs wil op zich nemen. - Wordt besloten die voorwaarde goed te keuren, behoudens het kopijregt, dat het Instituut zich wenscht voor te behouden.

Door den heer Potter wordt voorts de rekening en verantwoording ter tafel gebragt, mede bestemd om aan de algemeene vergadering te worden voorgelegd. $\mathrm{Na}$ onderzoek door den heer Engelhard wordt die rekening goedgekeurd.

Vervolgens wordt nog op voorstel van den Voorzitter besloten, om aan de leden, die zich nog bij geene afdeeling hebben aangesloten, een exemplaar te zenden der voor de afdeelingen vastgestelde Bepalingen, onder mededeeling der afdeeling, bij welke het Bestuur gemeend heeft hen te mogen opnemen.

Niets meer aan de orde zijnde wordt de vergadering gesloten. 